Article

\title{
Sliding Contact Wear Damage of EBM built Ti6Al4V: Influence of Process Induced Anisotropic Microstructure
}

\author{
Jae Joong Ryu ${ }^{1, *}$, Sanjay Shrestha ${ }^{1}$, Guha Manogharan ${ }^{2}$ and Jai K Jung ${ }^{3}$ \\ 1 Department of Mechanical, Industrial, and Manufacturing Engineering, Youngstown State University, \\ Youngstown, OH 44555, USA; sanjaykoid@gmail.com \\ 2 Department of Mechanical and Nuclear Engineering, Pennsylvania State University, University Park, \\ PA 16801, USA; gum53@psu.edu \\ 3 Department of Civil/Environmental and Chemical Engineering, Youngstown State University, \\ Youngstown, OH 44555, USA; jkjung@ysu.edu \\ * Correspondence: jjryu@ysu.edu; Tel.: +1-330-941-2396
}

Received: 17 November 2017; Accepted: 9 February 2018; Published: 13 February 2018

\begin{abstract}
Process-induced directional microstructure is identified as one of the key factors of anisotropic mechanical properties. This directional property significantly affects surface contact fatigue and corrosion of electron beam melting (EBM) built biomedical implants. In the current study, material removal on EBM built titanium (Ti6Al4V) subjected to reciprocating motion of commercially pure titanium spherical slider is investigated to identify the influence of the process-induced layered structure and environments on wear damage. Specimens developed by two different build orientations are mechanically stimulated using different sliding directions with nominally elastic normal load in dry, passivating, and synovial environments. It was noticed that EBM orientation significantly changes wear behavior in ambient environment. Wear resistance of mill-annealed Ti6Al4V was improved in passivating environment. Implications to improve useful life of orthopedic implants are discussed.
\end{abstract}

Keywords: sliding contact fatigue; electron beam melting; microstructure; medical implants

\section{Introduction}

Titanium alloys are the most important advanced materials for additive manufacturing (AM) technologies in medical and aerospace systems [1]. Especially, AM technology has been successfully implemented to suit functional orthopedic implants with tailored mechanical properties [2]. Graded surface structures fabricated by additive process can produce implant materials with similar cellular structures and mechanical properties that improve the integrity of implant-bone cell interface [3]. Design freedom of AM enables to develop anatomic custom built joints for individual patients [4]. However, the anisotropic grain structure due to directional solidification of partially molten metal would affect tribological behaviors of load bearing joint implants $[5,6]$. Repeated small scale sliding contact (fretting fatigue) in corrosive physiological environment induces progressive damage on modular interface of joint implants limiting their useful life [7,8]. This surface fatigue damage results in formation of soluble debris that can migrate locally or systemically. Wear debris and metal corrosion product may induce adverse effect such as inflammation and necrosis at surrounding soft tissue [9]. The modular total hip replacement (THR) consists of acetabular socket, femoral head and femoral stem as shown in Figure 1. Femoral head and stem are connected by interlocking tapers which form a crevice [10]. Titanium (Ti6Al4V) powder generally makes up the femoral stem through electron beam melting (EBM) [11]. Ti6Al4V is the primary choice for the femoral stem material due to its superior 
mechanical properties and corrosion resistivity [12] and is used in the present experimental study. Although it is well accepted that Ti6Al4V has a superior corrosion resistance due to the formation of protective oxide layer during fretting damages, recently reported work on Ti6Al4V implants addressed significant implant damages and failures by fatigue wear and corrosion [13]. Especially, investigations on tribological responses of AM built Ti6Al4V joint implants have not been conducted to understand influence of process-induced microstructure on fretting corrosion.

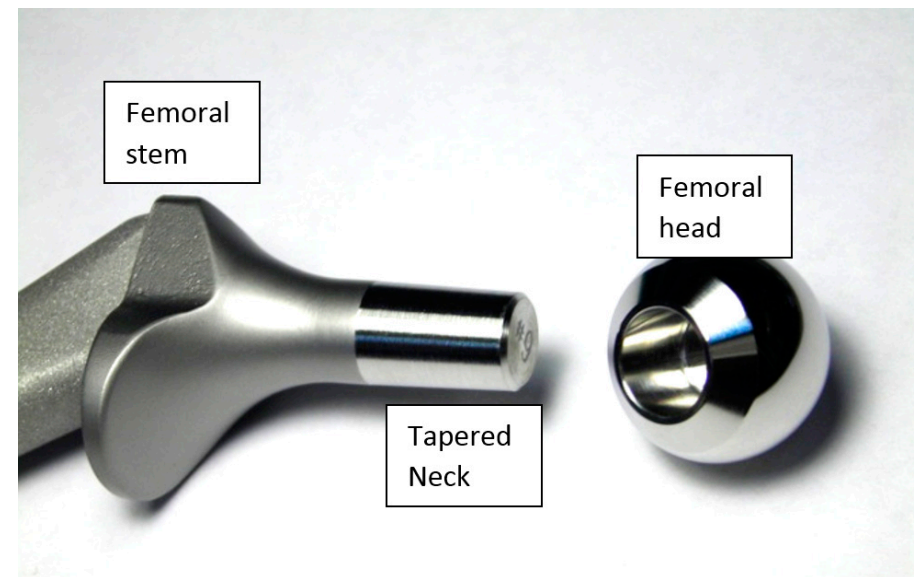

Figure 1. Sample of modular total hip replacement (THR).

A typical EBM built Ti6Al4V microstructures are presented in Figure 2c,d. Large columnar grains were developed in the direction of AM layer deposition. The present study investigates the impact of anisotropic structure due to directional solidification on wear mechanisms in ambient, passivating and synovial environments. Two groups of EBM built Ti6Al4V specimens were manufactured by two different build orientations. Two faces, perpendicular to layers and parallel to layers, were subjected to reciprocating motion of titanium sphere using an instrumented nanoindenter to apply known levels of contact stress. The resultant wear volume was compared with wear of mill-annealed Ti6Al4V surface. Wear damages were correlated with build directions and surrounding environments.

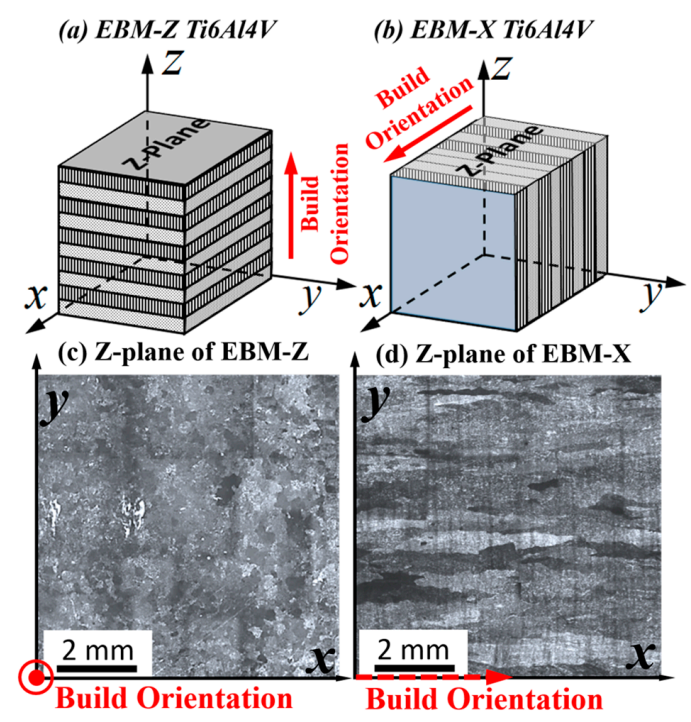

Figure 2. Graphical illustration of specimen preparation: (a) Electron beam melting (EBM) layered in $Z$ direction (EBM-Z); (b) EBM layered in X-direction (EBM-X); (c) equiaxed grain morphology of EBM-Z Ti6A14V; (d) columnar grains of EBM-X Ti6Al4V. 


\section{Approach}

In order to investigate the effects of AM process-induced surface anisotropy on surface damage mechanisms, Ti6Al4V samples developed by two different build orientations are tested by micro scale sliding contact. Fundamental mechanical properties including modulus of elasticity, hardness and yield strength of each group of specimens were measured by instrumented nanoindentation technique [14-17]. Micro scale grain morphology was observed and compared to understand the influence of microstructures on mechanical and tribological characteristics. A sliding wear (linearly reciprocating pin-on-flat) scheme in ambient, passivating, and synovial environments was employed to investigate the effect from process-induced properties on the tribocorrosion of AM made Ti6Al4V joints. Commercially pure $(\mathrm{CP})$ grade-2 titanium spheres with $1 \mathrm{~mm}$ diameter were selected to simulate metal-on-metal contact at modular interface of total hip joint replacement.

\subsection{Materials Description}

The materials used in this study are Ti6Al4V manufactured by standard EBM using Arcam Q10 (Mölndal, Sweden) with layer thickness of $50 \mu \mathrm{m}$ and powder size of approximately $45 \sim 106 \mu \mathrm{m}$ and traditionally manufactured mill-annealed Ti6Al4V supplied by ATI Allvac Corp. (Monroe, NC, USA). The chemical composition of the alloy provided by the manufacturers is presented in Table 1. To investigate the process induced anisotropic properties of EBM manufactured Ti6Al4V, specimens fabricated to a cube $\left(15 \times 15 \times 15 \mathrm{~mm}^{3}\right)$ were grouped in terms of layer orientations. As illustrated in Figure $2 \mathrm{a}, \mathrm{b}$, square layers $\left(15 \times 15 \mathrm{~mm}^{2}\right)$ are added along $\mathrm{z}$ - and $\mathrm{x}$-directions to prepare EBM- $Z$ and EBM-X surfaces, respectively. Z-planes of each group of specimens were subjected to reciprocating sliding contact. Mill-annealed Ti6Al4V samples were cut from 1-inch diameter cylinders into 5-mm thick disks by electronic discharge machining to minimize residual stresses. Specimens cut into required dimensions were mounted on phenolic disks to prepare the refined surface finish. In order to perform nano- and micro-scale mechanical tests, the sample surfaces were polished to mirror-finished following standard metallographic sample preparation methods with successive grit polishing to 4000 grit followed by $0.06 \mu \mathrm{m}$ silica suspension on micro fiber cloth. The average roughness $R_{a}$ (centerline average) $=23.5 \pm 1.4 \mathrm{~nm}$ was obtained over $200 \mu \mathrm{m}$ length profiles. The progressive damage of native oxide layer and plastic deformation of metal surface will be an important consideration in determining the fretting corrosion mechanism.

Table 1. Chemical compositions of Ti6Al4V powder for electron beam melting.

\begin{tabular}{ccccccccc}
\hline \multicolumn{7}{c}{ Percentage Weight Composition (\%) } \\
\hline Elements & $\begin{array}{c}\text { Aluminum } \\
(\mathbf{A l})\end{array}$ & $\begin{array}{c}\text { Vanadium } \\
\mathbf{( V )}\end{array}$ & $\begin{array}{c}\text { Carbon } \\
\mathbf{( C )}\end{array}$ & Iron (Fe) & $\begin{array}{c}\text { Oxygen } \\
\mathbf{( O )}\end{array}$ & $\begin{array}{c}\text { Nitrogen } \\
\mathbf{( N )}\end{array}$ & $\begin{array}{c}\text { Hydrogen } \\
\mathbf{( H )}\end{array}$ & $\begin{array}{c}\text { Titanium } \\
\mathbf{( T i )}\end{array}$ \\
\hline EBM & 6 & 4 & 0.03 & 0.1 & 0.15 & 0.01 & 0.0003 & Balance \\
Mill-annealed & 6.37 & 4.04 & 0.032 & 0.21 & 0.17 & 0.028 & $\mathrm{n} / \mathrm{a}$ & Balance \\
\hline
\end{tabular}

\subsection{Mechanical Characterization}

Nanoindentation tests are performed on mill-annealed, EBM-X and EBM-Z Ti6Al4V samples with a nanomodule mechanical tester from Nanovea (Irvine, CA, USA). In order to illustrate early stage of surface contact damage, small-scale indentation technique would be the better characterization method to determine the near-surface properties. Indenter contact load changes were monitored with indenter penetration depths. A series of nanoindentation tests results were mapped to represent local mechanical properties and averaged to determine system properties on the finished surfaces. Standard diamond Berkovich indenter is employed to determine elastic modulus and hardness $[14,15]$. A typical procedure of indenter motion was performed: Initial contact at $0.1 \mathrm{mN}$, increase indenter load at the rate of $280 \mathrm{mN} / \mathrm{min}$ up to peak load of $140 \mathrm{mN}$, withdraw the tip at the same rate of penetration, and finally complete separation of the tip from specimen surface. Unloading step of 
the indenter load-displacement was observed to evaluate the rate of load change with respect to indenter depth. This rate is called indentation modulus that is directly related to elastic recovery of the specimen surface.

In order to determine yield strength, 5- $\mu \mathrm{m}$ diameter cylindrical diamond indenter was employed [16,17]. Indentation steps were performed in a similar manner: initial contact at $0.1 \mathrm{mN}$, increase indenter load at the rate of $200 \mathrm{mN} / \mathrm{min}$ up to peak load of $100 \mathrm{mN}$, withdraw the tip at the same rate of penetration, and finally complete separation. Due to the larger contact area of cylindrical indenter tip, indentation rate and peak load were selected lower than Berkovich indentation test. The correlation between indentation load and penetration depth during the loading step is used to determine the yield point. Indenter load at the maximum slope of the load-depth response is considered to initiate yielding of the surface. Indenter load at yield point and constant circular contact area were used to determine local yield strength point. A total of nine sets of indentation tests were repeated by using mapping feature of $3 \times 3$ arrays on the EBM-Z, EBM-X and mill-annealed samples. Each series of mapped indentations covers an area of $100 \times 100 \mu \mathrm{m}^{2}$.

\subsection{Microstructure}

In order to understand the relation of process-induced anisotropy on EBM Ti6Al4V and its resulting mechanical properties, microstructures and grain morphology of EBM Ti6Al4V were observed and compared with those of mill-annealed Ti6Al4V. The samples are mirror finished and are prepared for optical metallography by etching in a solution of $100 \mathrm{~mL} \mathrm{H}_{2} \mathrm{O}, 6 \mathrm{~mL} \mathrm{HNO}_{3}$, and $3 \mathrm{~mL} \mathrm{HF} \mathrm{[18].}$ The etched samples on their Z-plane are observed in a Zeiss A/M optical microscope under dark and bright light scopes. Further, EBM-X and EBM-Z are investigated by X-ray diffraction (XRD) and Energy Dispersive Spectroscopy (EDS) to determine the phases present and the chemical composition of individual phases. Crystallographic phase identification is obtained by XRD using a Bruker Prospector CCD Diffractometer copper micro-source X-ray tube at room temperature (Bruker, Billerica, MA, USA). XRD (Bruker, Billerica, MA, USA) are carried out in the range of 20-90 for a period of $2 \mathrm{~h}$. EDS (Jeol, Peabody, MA, USA) analysis in the form of horizontal line scan is conducted along a $10 \mu \mathrm{m}$ line scan from etched samples to determine the chemical composition and atomic weight percentages of the elements present from the scanned area.

\subsection{Wear Experiment}

CP grade-2, $1 \mathrm{~mm}$ diameter titanium spheres were used to conduct the reciprocal sliding wear test at the similar materials interface. Similar metal surface pair increases the adhesional friction, and therefore, the greater shear load would induce adhesive wear under nominally elastic contact before the significant plastic deformation-dominant abrasional wear is initiated. The titanium sphere was attached to Nanovea nanomodule performing reciprocating motion at a constant speed of $100 \mu \mathrm{m} / \mathrm{s}$ for 30 min against Ti6Al4V sample surfaces to perform frictional interactions at the similar metal interface. Wear tests with two different directions of sliding motion were repeated to inspect consequence of sliding directions and EBM build orientations on wear response as shown in Figure 3. To investigate transversely isotropic surface of EBM-Z specimens, two sliding directions were selected at $45^{\circ}$ from each other. First sliding direction was parallel to one edge, $x$-coordinate in Figure $3 a$, of the square plane and the second group sliding tests were performed along an axis at $45^{\circ}$ from $x$-coordinate. It was expected for z-plane on EBM-X specimens to have anisotropic property as the columnar grains present distinctive directional structure that is parallel to build orientation ( $\mathrm{x}$-coordinate). Two sliding contact directions were selected along $\mathrm{x}$ - and $\mathrm{y}$-coordinates, respectively. Wear tests on mill-annealed Ti6A14V surfaces were also performed along directions at every $30^{\circ}$. In order to objectively compare the wear response with respect to contact pressure, nominally elastic contact load was estimated based on Hertzian contact theory. Materials properties evaluated from indentation tests and the geometry of CP titanium spheres were used to determine real contact area and average contact load. Therefore, the same level of contact stress were applied on each specimen surface during the course of sliding 
contact experiments. With known yield strength of the Ti6Al4V specimens, elastic normal contact load was selected at $25 \%$ of yield pressure. The material properties of the CP grade- 2 titanium spheres are summarized in Table 2. Average half-contact radii evaluated from Hertzian contact model throughout the test were found to be in the range from 4.9 to $6.2 \mu \mathrm{m}$ for three specimens.

A total of 6 trials of wear experiments were performed in ambient at controlled humidity of $27 \pm 5 \%$ and temperature of $25 \pm 3{ }^{\circ} \mathrm{C}$. The same wear experiments were repeated 6 times in passivating environment of phosphate buffered saline (PBS) solution and artificial synovial environment. Hyaluronic acid (HA) at the concentration of $3 \mathrm{~g} / \mathrm{L}$ and bovine serum albumin (BSA) at the concentration of $19 \mathrm{~g} / \mathrm{L}$ were dissolved in PBS solution [19]. A custom design bath was manufactured from an ultra-high-molecular-weight-polyethylene cylinder to securely hold the specimen and to be mounted on the tester stage. Prior to the wear test, actual roughness and curvature were inspected to apply consistent contact pressure throughout experiments. Numbers of preliminary tests were conducted to evaluate the wear of $\mathrm{CP}$ Ti-sphere sliders by the continuous sliding. Test period (30 $\mathrm{min}$ ) and nominal contact stress were determined based on minor change in radius of curvature on the CP Ti-sphere tip.

During the course of sliding contact tests, friction (lateral) force and normal force were monitored to evaluate changes in friction coefficients using the high resolution friction stage (Nanovea, CA, USA). The progressive change of friction coefficients was correlated to the wear volume of each specimen.

Table 2. Mechanical properties of commercially pure (CP) grade-2 titanium spheres.

\begin{tabular}{cccccccc}
\hline Modulus of Elasticity & Poisson's Ratio & \multicolumn{4}{c}{ Percentage Weight Composition (\%) of Elements } \\
\hline \multirow{2}{*}{$103 \mathrm{GPa}$} & \multirow{2}{*}{0.35} & Carbon & Iron & Oxygen & Nitrogen & Hydrogen & Titanium \\
& & 0.08 & 0.3 & 0.25 & 0.03 & 0.015 & Balance \\
\hline
\end{tabular}

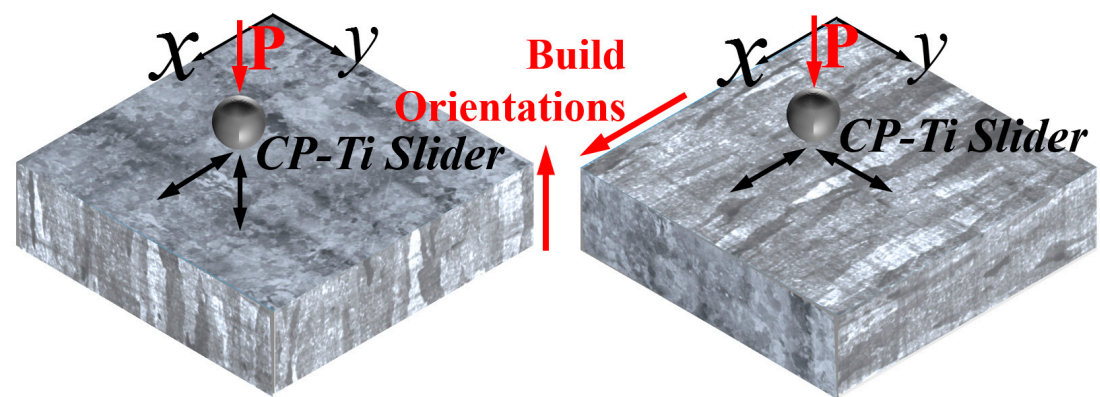

(a) EBM-Z Ti6Al4V

(b) EBM-X Ti6Al4V

Figure 3. Illustration of slider motions of fatigue wear test on (a) EBM-Z and (b) EBM-X samples.

For each test, an initial $250 \mu \mathrm{m} \times 250 \mu \mathrm{m}$ optical scan at the randomly selected region was recorded using Nanovea profilometer. The specimen was then moved under the CP Ti-spherical slider for wear test. Relative positions between the profilometer sensor and slider were calibrated to deliver the desired position of the specimen to be tested. $100 \mu \mathrm{m}$ reciprocal sliding test was then performed at the center of the scanned area. The slider was reciprocated at $1 \mathrm{~Hz}$ for $30 \mathrm{~min}$ at $25 \%$ of yield strength of the specimen. After $30 \mathrm{~min}$, the specimen was moved under the profilometer sensor to obtain the final surface configuration in $250 \mu \mathrm{m} \times 250 \mu \mathrm{m}$ area and recorded. Final surface data after sliding contact test was subtracted from initial surface data to precisely quantify wear volume. A total of 6 wear tests at contact loads corresponding to $25 \%$ of yield stress were conducted in three different environments and the Ti-sphere wear was also monitored to determine average contact stress throughout the wear tests. The optical profilometer was used to determine tip damage. 


\section{Results}

\subsection{Microstructure}

In order to correlate the tribological behavior to the build direction, microstructures of mill-annealed, EBM-Z and EBM-X Ti6Al4V specimens were observed using scanning electron microscope (SEM). The grain morphology of mill-annealed Ti6Al4V specimen illustrated a mixture of equiaxed alpha grains and alpha/beta colonies as in Figure 2a that is a typical configure of mill-annealed Ti6Al4V. The microstructure of EBM-X sample consists of large columnar grains parallel to the build direction as shown in Figure 2d. In addition to the columnar grains, layered patterns are clearly visible that are perpendicular to columnar grains. EBM-Z surfaces present equiaxed grain morphology which are cross sections of the columnar grains (Figure 2c) $[20,21]$. These are typical microstructures observed in the EBM built Ti6Al4V surfaces depending upon the build directions. The high magnified micro image observations of EBM-X in Figure 4c shows the grains epitaxially formed due to the rapid solidification of the small melt pool extended through many layers and high thermal gradient in the build direction. The $\alpha$-grain boundary was also found. On the other hand, the microstructure of EBM- $Z$ surface consists of relatively equiaxed grains, as shown in Figure $4 \mathrm{~b}$. This is the typical morphology of prior $\beta$ grains in cross-sectional planes perpendicular to the EBM layers [19]. In both cases, the microstructure morphology is similar and represents a typical Widmanstätten or basket-weave morphology, reported in literature for Ti6Al4V alloys [22,23]. The microstructure of both EBM-X and EBM-Z consists of alternating layers of acicular $\alpha$ phase separated by thin layers of retained $\beta$ phase. In order to confirm the existence of $\alpha$ and $\beta$ phases, $X$-ray diffraction patterns were collected from the z-planes of EBM-Z and EBM-X samples and were summarized in Figure $4 \mathrm{~d}$. As expected, most of the XRD peaks originate from $\alpha$ phase. Generally $\beta$ peaks are not clearly distinguished in the diffraction patterns [21,24]. The average fractions of element concentration of $\alpha$ and $\beta$ phases are summarized in Table 3.
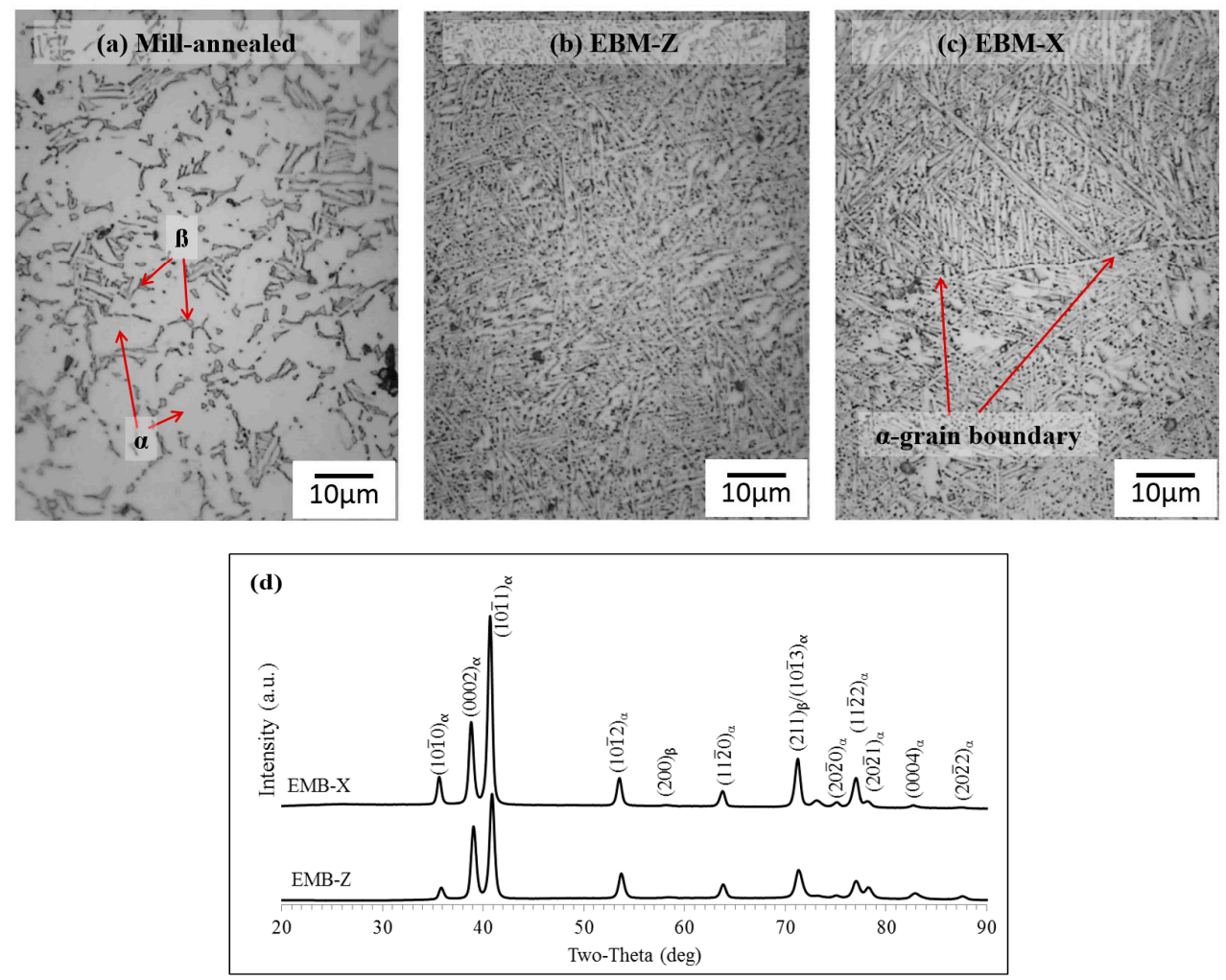

Figure 4. Microstructures of (a) Mill-annealed, (b) EBM-Z, and (c) EBM-X, and (d) X-ray diffraction patterns for EBM-Z and -X samples. 
Table 3. The average element concentration of $\alpha$ and $\beta$ phases, including statistical standard deviation (based on ten measurements).

\begin{tabular}{ccccc}
\hline \multicolumn{2}{c}{ Phases } & Ti & Al & V \\
\hline \multirow{2}{*}{$\alpha$ phase } & wt $\%$ & $89.77 \pm 0.74$ & $6.04 \pm 0.17$ & $4.19 \pm 0.82$ \\
& at $\%$ & $85.96 \pm 0.64$ & $10.26 \pm 0.27$ & $3.78 \pm 0.74$ \\
\hline \multirow{2}{*}{$\beta$ phase } & wt $\%$ & $86.29 \pm 1.63$ & $5.27 \pm 0.24$ & $8.44 \pm 1.86$ \\
& at $\%$ & $83.29 \pm 1.35$ & $9.04 \pm 0.39$ & $7.67 \pm 1.71$ \\
\hline
\end{tabular}

\subsection{Mechanical Properties}

Depth-sensing nanoindentation technique was employed to characterize the mechanical properties for EBM built Ti6Al4V parts. Using a standard Berkovich tip, a total of 9 indentation tests were performed on the respective EBM-Z, EBM-X and mill-annealed sample surfaces. The mill-annealed sample was set as a control group which provided the elastic modulus and indentation hardness. Indentation stiffness is obtained from the slope of the unloading portion of a load-displacement curve, which are used to calculate elastic moduli for each Ti6Al4V builds. Indentation hardness was determined using the projected contact area that was approximated by the indenter geometry and depth of indenter tip [25]. The averaged elastic moduli and indentation hardness of each specimen represent individual mechanical property of the corresponding EBM directions. Although the small contact test is hardly able to dictate the entire surface and overall properties for large grained specimen, however, a large number of measurements using mapping feature throughout the surface could present an averaged value on the large grained mill-annealed surface. The large error-bar (standard deviation) of yield strengths of mill-annealed surface would illustrate the variations of the measured yield strength over the variable grain structures. Figure 5 summarizes indentation test results. While Berkovich indentation test results present superior mechanical properties on EBM built Ti6Al4V as elastic moduli and yield strengths are higher than those of mill-annealed Ti6Al4V, indentation hardness of mill-annealed Ti6AL4V is superior to that of EBM-Z and EBM-X. It is evident that the averaged value of yield strength for mill-annealed surface is lower than those values for EBM-X and EBM-Z surfaces as shown in Figure 5c. It may be because contact areas used to characterize hardness that is affected by microstructures and residual stress developed during manufacturing process [26,27].

(a) Berkovich indentation

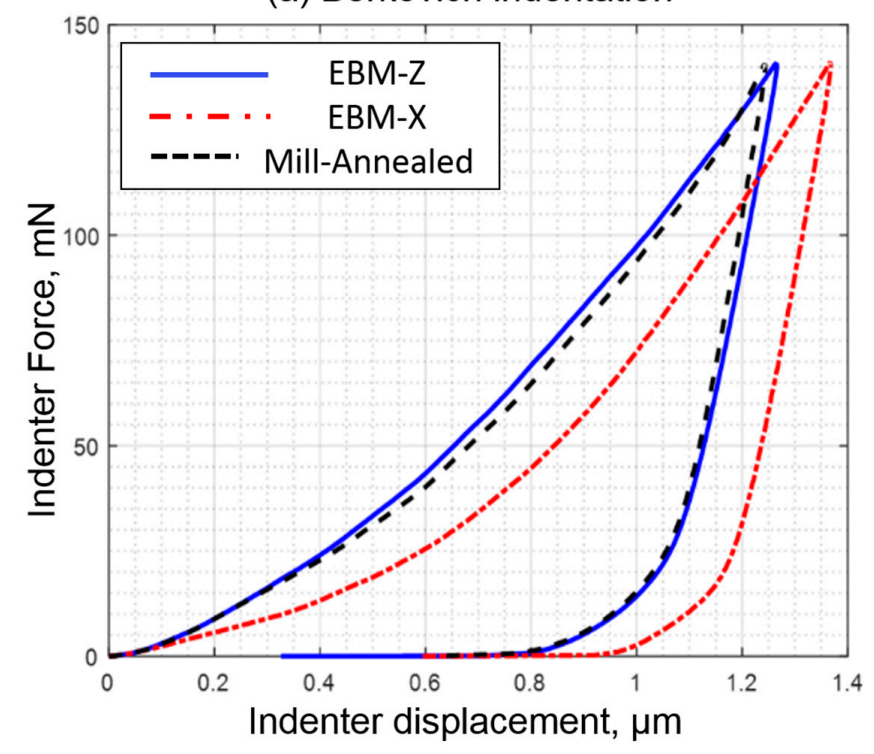

Figure 5. Cont. 

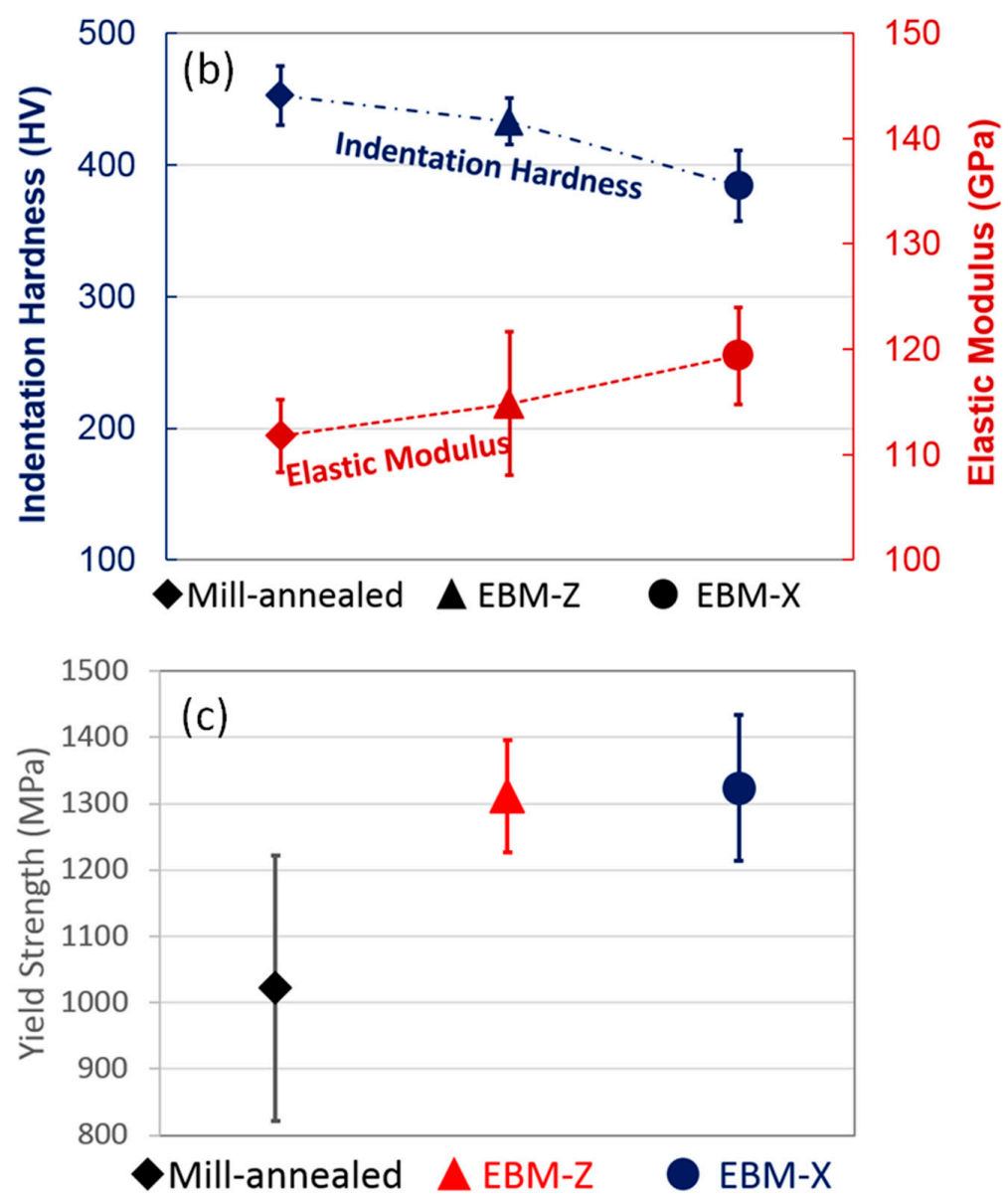

Figure 5. Comparison of representative load-displacement curve from (a) Berkovich indentation, (b) indentation hardness and elastic modulus, and (c) yield strength of mill-annealed, EBM-Z, and EBM-X Ti6Al4V.

\subsection{Wear of Ti6Al4V Surfaces}

From nanoindenter-based micro scale sliding contact experiments, wear volume was obtained for EBM built Ti6Al4V with two different build orientations in ambient and aqueous environments as shown in Figures 6-8. The error bars represent standard errors resulted from five repeated experiments and deviations in wear depth evaluations from digital image process. A significant effect of manufacturing process on wear mechanism was found during dry sliding contact. Sliding contact wear in ambient environment (Figure 6) indicates that annealed Ti6Al4V surface with $10 \mu$ m equiaxed- $\alpha$ grains has less wear resistance. Wear volume on EBM-X with anisotropic grain morphology illustrates more sensitive to sliding direction compared to EBM-Z with transversely isotropic microstructure. Sliding motions parallel to layers (perpendicular to build direction) results in more than double of the wear volume induced by sliding motions perpendicular to layers (parallel to build direction). Reciprocal contact in PBS solution (Figure 7) indicates that the passivating condition (PBS; pH 7.4) considerably improves wear resistance on mill-annealed Ti6Al4V surface; whereas the passivating condition does not significantly influence wear response on EBM built Ti6Al4V. However, anisotropic effect of sliding directions on EBM-X is not obvious in PBS. Simulated synovial fluid (Figure 8) reduces wear damage on all specimens. Protein layer attached to the metal surface drastically improves liquid film lubrication and decrease the surface fatigue response. In addition, wear rate in synovial condition is mostly insensitive to the surface anisotropy, whereas dry wear is a strong function of process-induced microstructures. 


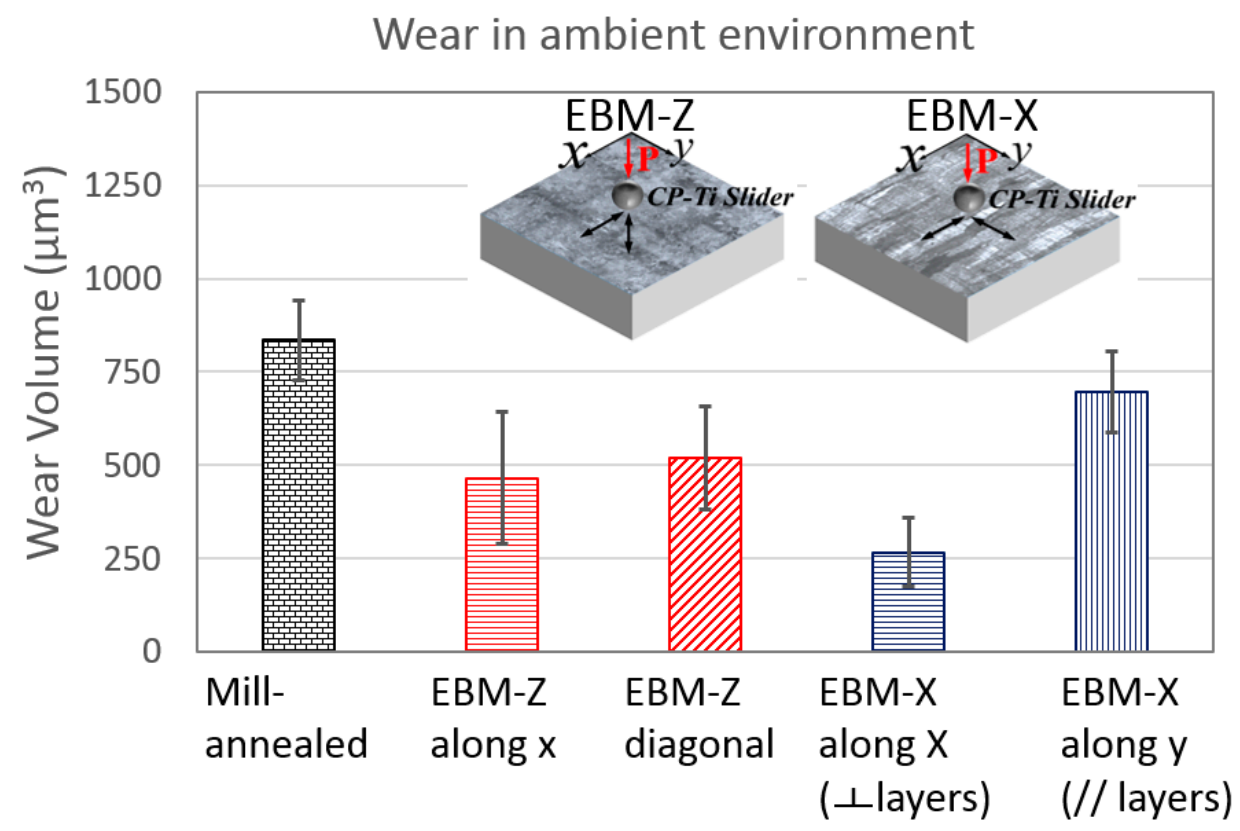

Figure 6. Fatigue-wear damage in ambient environment.

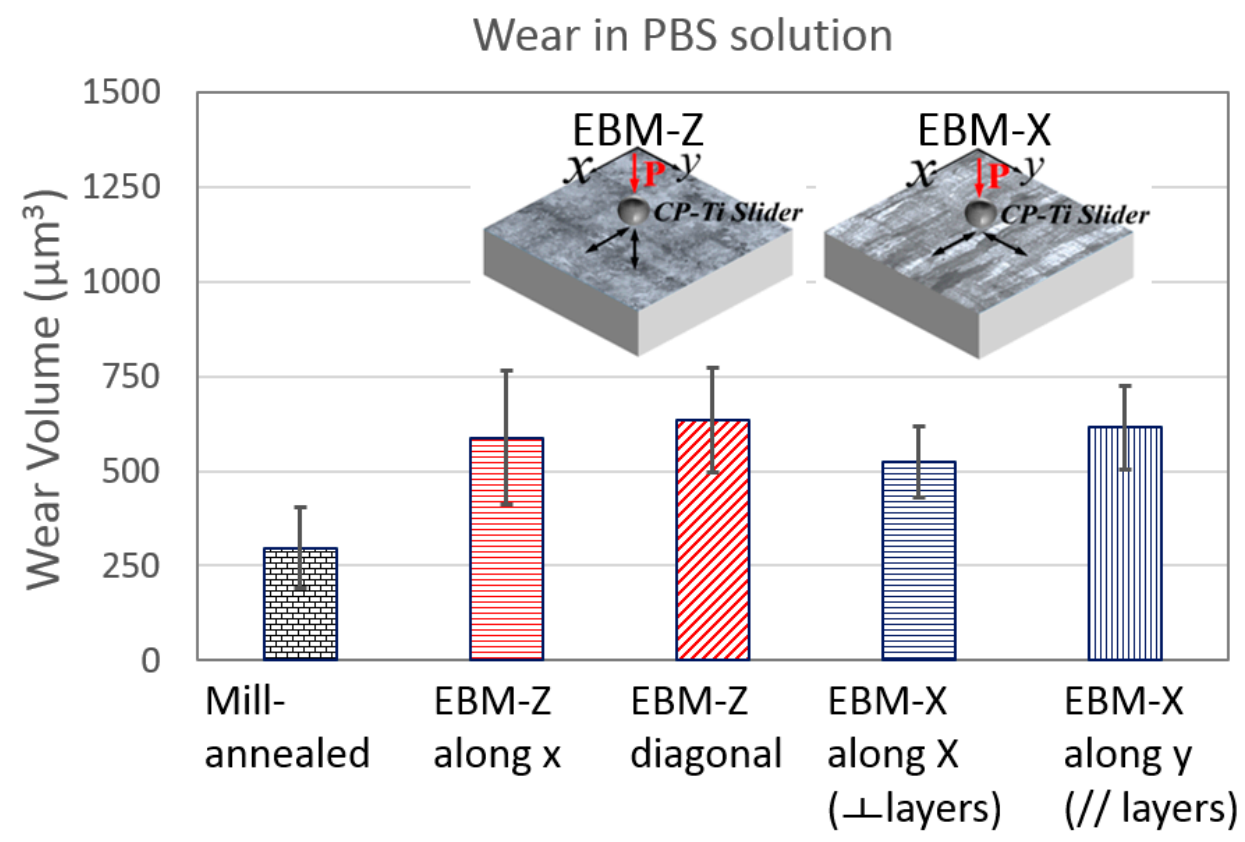

Figure 7. Fatigue-wear damage in PBS solution. 


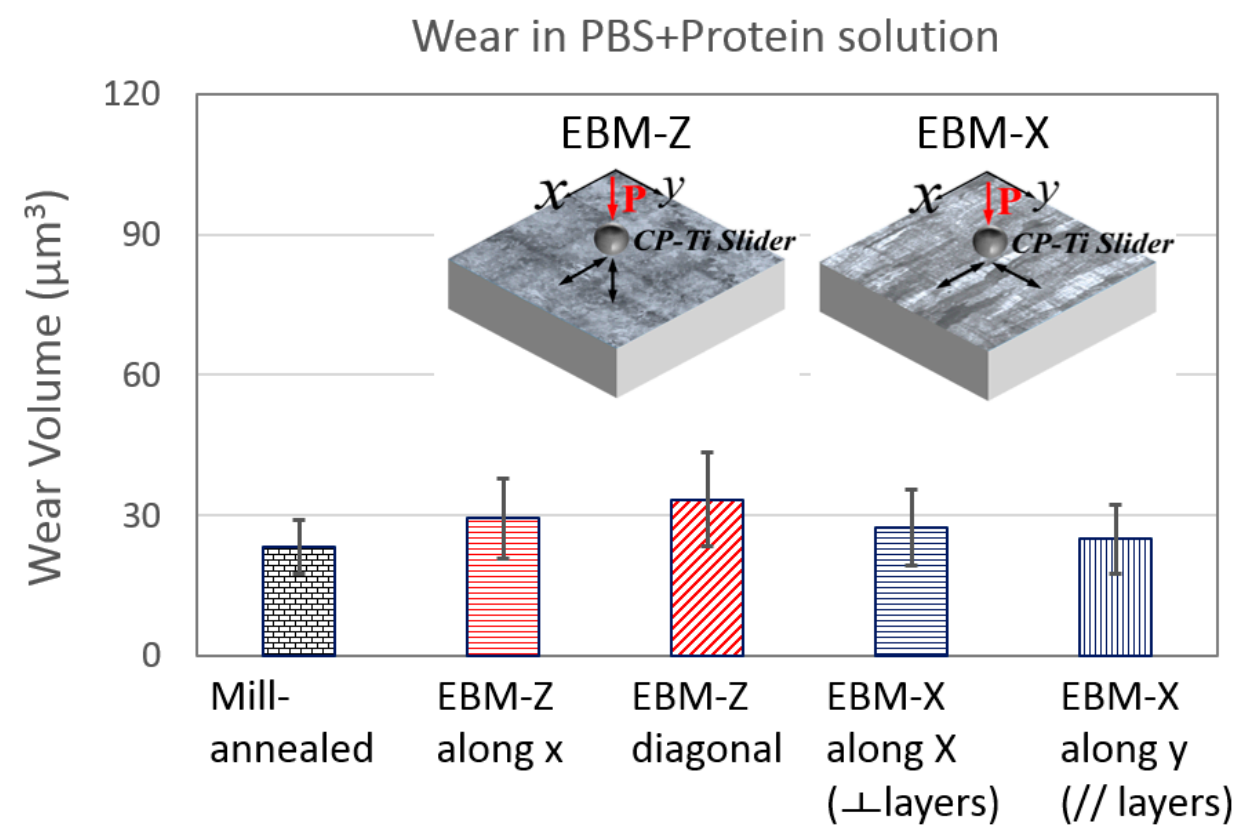

Figure 8. Fatigue-wear damage in simulated synovial fluid.

\section{Discussion}

The experiments were designed to investigate the influence of directionally solidified structure on wear resistance during surface fatigue contact, i.e., repeated frictional contact in nominally elastic ranges. In dry condition, the volume of material removed is a strong function of microstructures produced by additive process, resultant elastic moduli and yield strengths, and sliding directions. Fine lamellar $\alpha$-phase in the large $\beta$ grains in EBM built specimens improved the yield strength that will critically affect resistivity of sliding contact wear in ambient environment. This result implies that EBM process-induced layered structure plays an important role in dry wear damage process. Interestingly, while the sliding direction parallel to EBM layer on EBM-X specimen presents accelerated wear process, the sliding direction perpendicular to EBM layer on EBM-X specimen results in suppressed wear in ambient environment.

The elastic sliding contacts of titanium sphere in ambient environment would result in mild oxidative wear and metal adhesion through the damaged oxide at this early stage of sliding contact. The continuous repetition of break-reformation of oxide layer and development-failure of adhesive junction is a prominent wear mechanism [28]. Microscopic image from SEM illustrates separated layers of wear pile-ups in dry condition as shown in Figure 9a,b. The magnified image of wear pile-up highlighted in Figure 9a illustrates the oxide wear debris and larger metal wear particles. Small light particles in the outer layer of the pile-up surrounding wear trench are oxide debris and dark layer is plastically deformed metal transferred by reciprocating motion of the slider. It may describe the transition of wear mechanisms from mild progressive oxidative wear to large adhesive wear. In addition to the combination of oxide damage-metal adhesion, small-scale plastic deformations would be accumulated at the subsurface during repeated reciprocating sliding motions [29]. Therefore, the greater wear volume of mill-annealed surface can be explained by the accumulated dislocations due to greater ductility and less yield strength obtained from nanoindentation tests. As a result, the titanium-titanium interface increases dry sliding coefficient of friction as the interfacial shear strength increases as much as bulk shear strength of titanium surface. The friction coefficients obtained from lateral force presented a similar result from dry sliding wear response. Especially, a large wear volume on mill-annealed surface agreed to the greater friction coefficient, while EBM-X surface disturbed by $\mathrm{x}$-direction sliding contact agreed to the lowest friction coefficient as illustrated in Figure 10. However, 
friction coefficient of EBM-X surface disturbed by $x$-direction sliding drastically increased at the first 10 cycles of the sliding motions and decreased in the later 10 following cycles. It is a different from dry sliding wear of other specimens as other surfaces gradually increase friction coefficients and reached to a steady state fiction. However, EBM-X surface continuously increase friction coefficients during $x$-direction sliding contact. Therefore, the increased shearing force on EBM-X surface during $\mathrm{x}$-direction sliding throughout the sliding cycles would accelerate accumulation of dislocations at the subsurface and delamination wear would be followed $[29,30]$. Consequently, the results imply that the wear mechanism of titanium-titanium interface in dry is critically dependent on EBM process-induced layered structure and sliding directions.

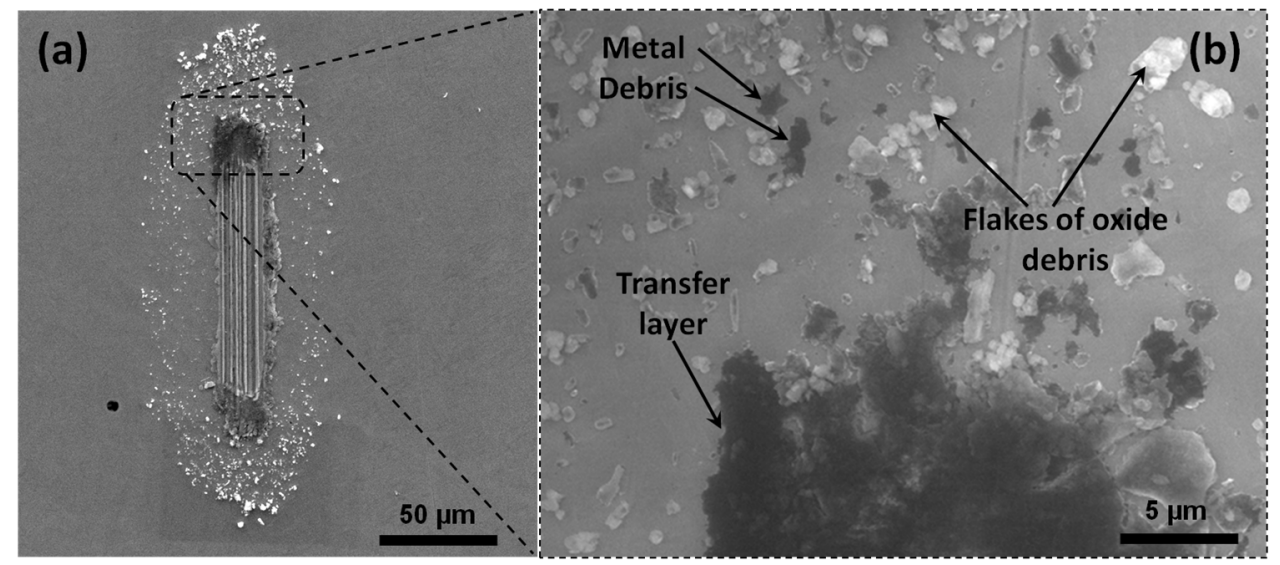

Figure 9. (a) Microscopic images of wear debris produced on EBM-X in dry condition; (b) magnified image of the highlighted wear pile-up.

The wear dependence of layer orientations on EBM-X and EBM-Z parts observed in aqueous conditions seems insignificant. The experimental result in PBS solution illustrates that the mill-annealed surface has superior wear resistance as the wear volume and reduced friction coefficient were notably reduced in passivating environment. It is evident that the dependence of sliding directions on wear of EBM-X is insignificant in the aqueous environment (Figures 7 and 8). It is because the presence of thin fluid film reduces the friction coefficient as in Figure 10c,d and assist rapid oxide film reformation. In addition, the rapid solidifications during EBM process may develop residual stress field [31]. Elastic residual strains increase thermodynamic potential and ultimately accelerates electrochemical reaction of the mechanically disturbed surfaces $[32,33]$. However, recrystallization and grain growth during the final mechanical and thermal treatment through mill-annealing would reduce surface residual stress [34]. Therefore, the fundamental wear mechanism on EBM-built parts in PBS would be combined effect from electrochemical potential and mechanical disturbance. The microscopic inspection of wear damage in PBS solution is shown in Figure 11b. As opposed to the result shown in Figure 9a, wear pile-up was not observed on wear track in PBS and simulated synovial solution (Figure 11b,c). Liquid mediated contact would reduce the shear strength the slider-surface interface, and therefore, adhesive wear would be lesser in aqueous environment. It was noticed that the wear track width of EBM-Z produced by sliding contact in both liquids is larger than the wear trench in dry. Oxide-wear debris and produced small metal wear particles were agglomerated with newly produced wear debris and continuously plow the surface within the larger contact area. Due to increased contact area, plastic deformation by sliding contact would be suppressed while fretting corrosion damage will be the major surface damage mechanism $[35,36]$. Although the wear volume of mill-annealed surface was drastically decreased, the wear volume of EBM built Ti6Al4V parts was measured to be comparable to the wear volume produced during the dry sliding wear. 
(a) Friction Coefficients (Dry sliding)

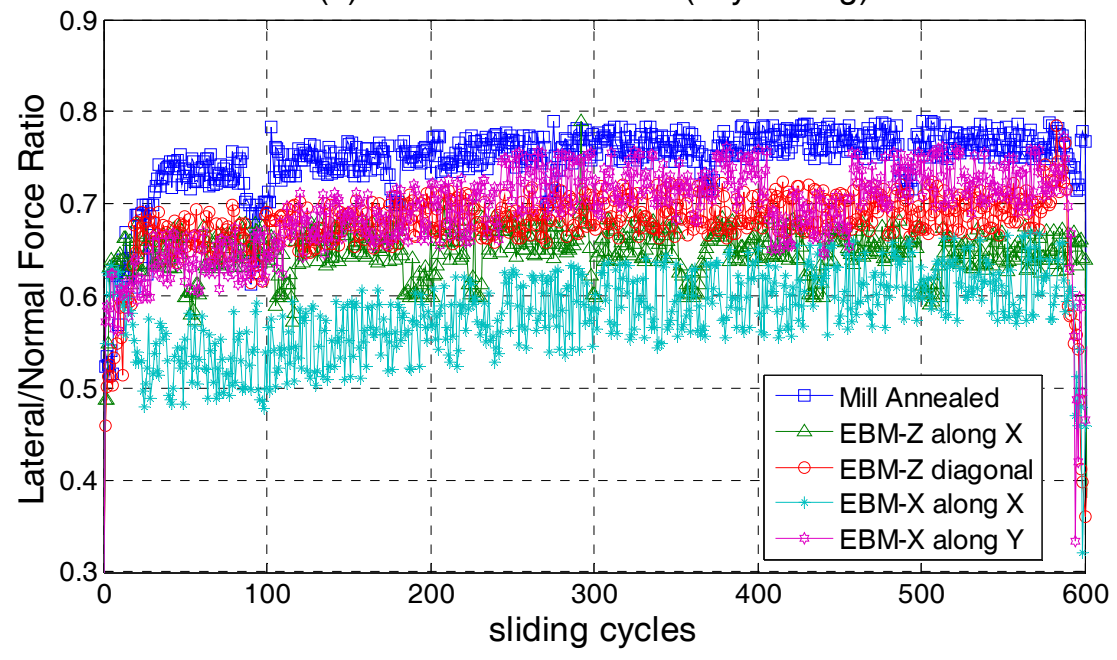

(b) Dynamic friction coefficients in ambient environment

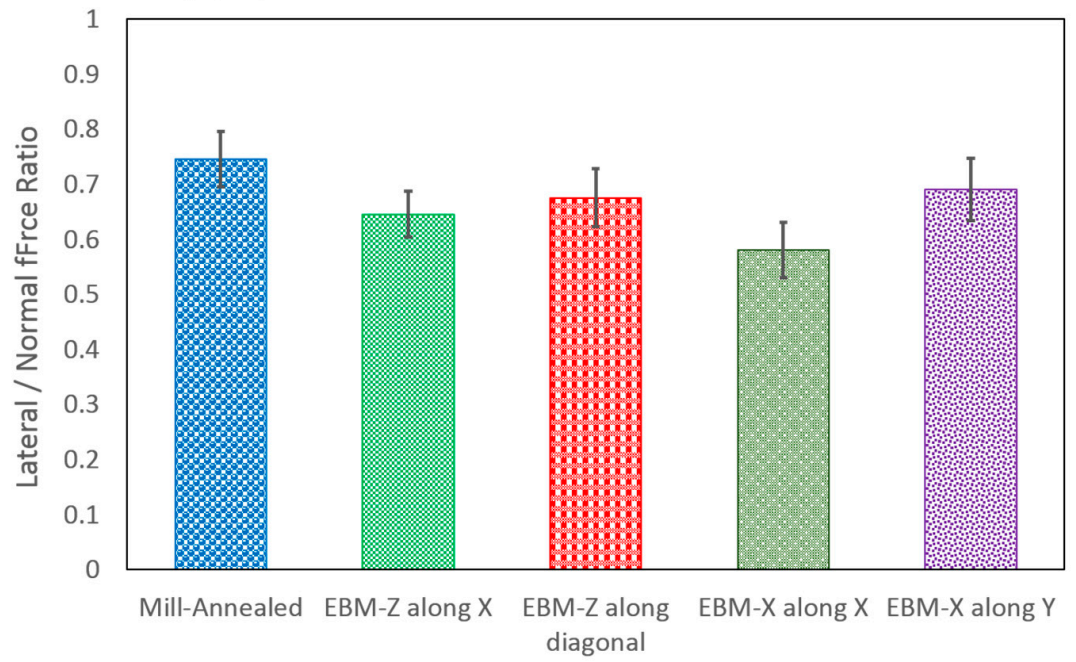

(c) Dynamic friction coefficients in PBS

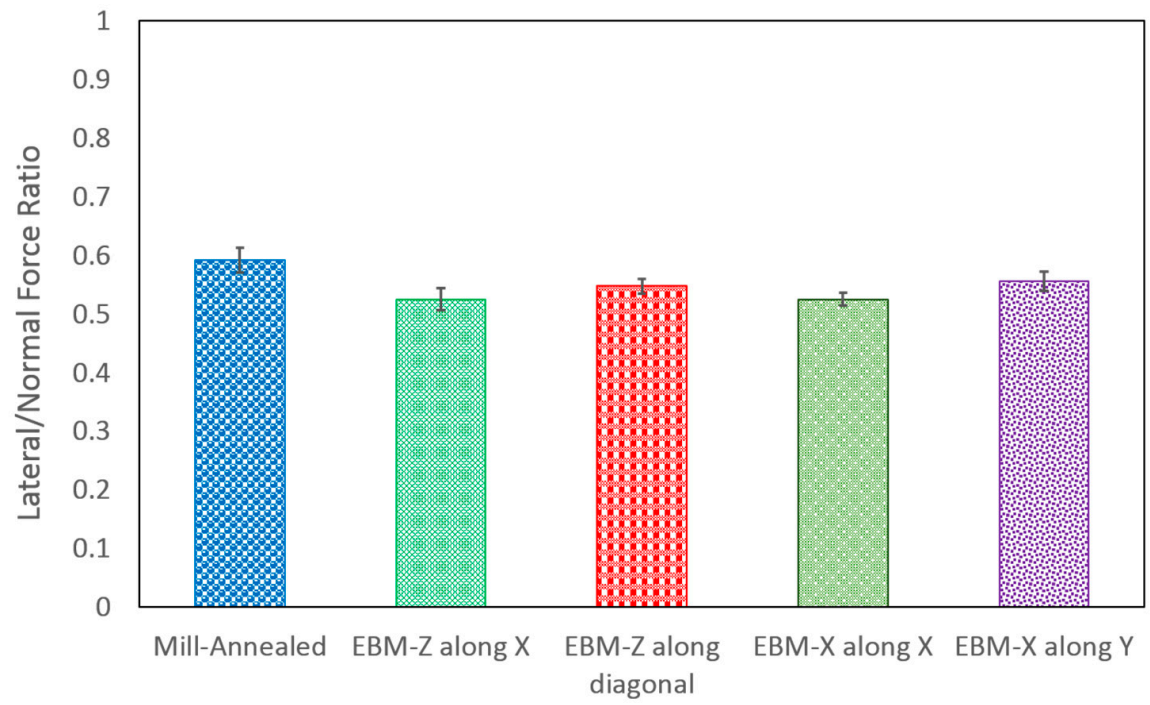

Figure 10. Cont. 


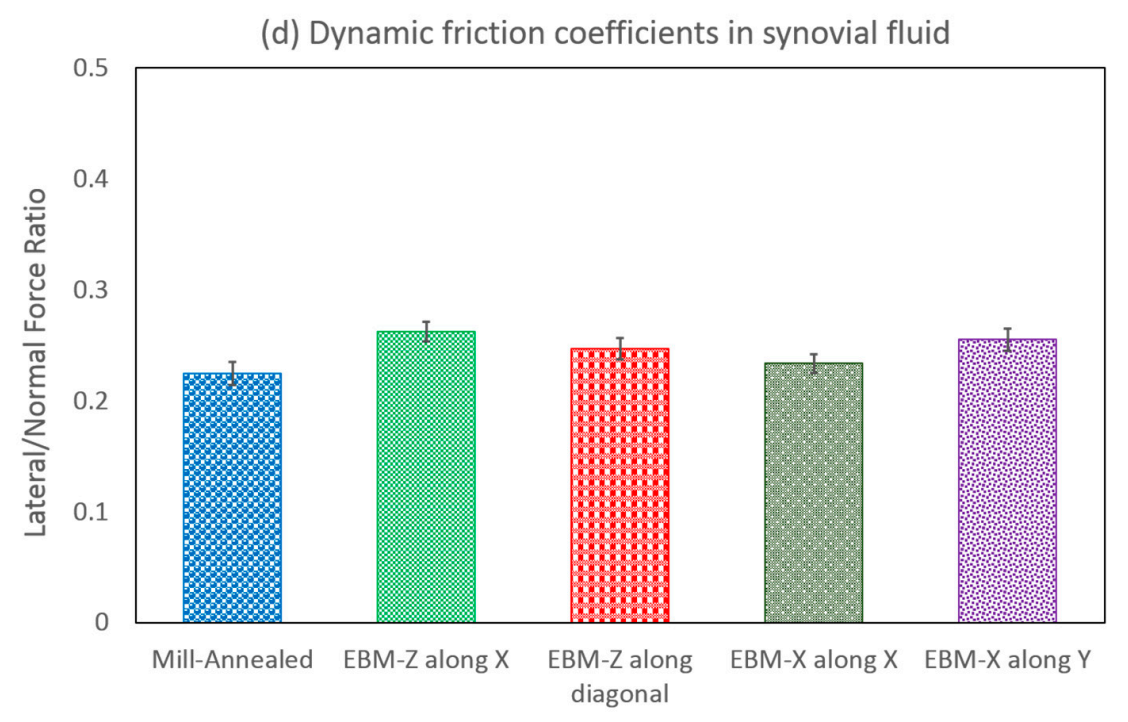

Figure 10. Evolution of friction coefficients: (a) Measured friction coefficients during dry sliding contact; (b) averaged friction coefficients in ambient; (c) averaged friction coefficients in PBS; (d) averaged friction coefficients in simulated synovial fluid.

Simulated synovial fluid drastically decreased the wear volume on all specimen surfaces as the bovine serum albumin attached to the physisorbed hyaluronic acid layer on Ti6Al4V surface and improved full liquid film lubrications $[19,37]$. As illustrated in Figure 10c, friction coefficients measured in synovial fluid were reduced and almost the same for all specimen surface. This adsorbed protein layer also protects the surface from electrochemical dissolutions of metal ions when the oxide layer was damaged.
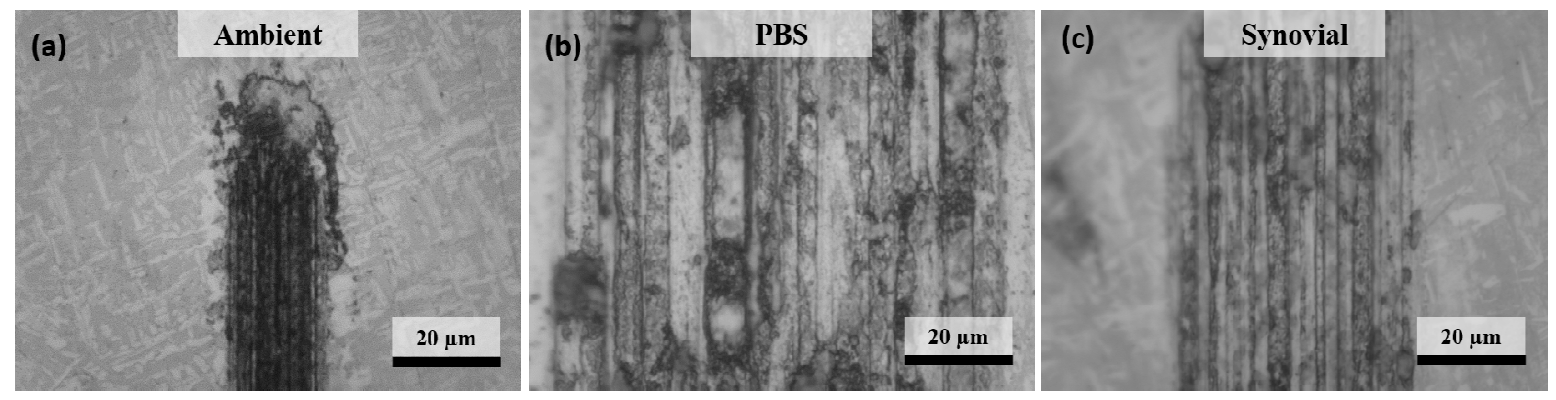

Figure 11. Wear damages on EBM-Z sample after reciprocating sliding contact in (a) ambient, (b) PBS, and (c) simulated synovial solution.

\section{Conclusions}

Additive manufacturing process-based argument on wear damage mechanism is proposed to explain how layer-by-layer process affect tribological response in different environments. The complex dependence of wear on anisotropic microstructure and environment suggests that the wear mechanism changes depending on electrochemical reactivity. In addition, the beneficial influences of chemical environment on mill-annealed Ti6Al4V surface may be exploited as possible avenues to reduce wear rate against fretting corrosion damage process. Also, experimental result presented that the passivating environment significantly reduced the sensitivity of anisotropic wear response on EBM-built parts. In classical literature in tribology, it is well accepted that the smaller grain morphology obtained generally yield enhanced fatigue and wear resistance in metals [38,39]. The wear depths observed on mill-annealed surface were typically greater than EBM surfaces in dry condition. In passivating 
environment, however, in our experiments, the wear mechanism illustrated that the wear depths on EBM surfaces were greater than mill-annealed surface. In addition, the clear tribological anisotropy (sliding direction sensitivity on wear) of EBM-X presented during dry sliding tests became insignificant in PBS solutions. This may be caused by accelerated corrosion with established residual stress, causing greater wear rate on EBM-built parts. Protein mediated lubrication drastically reduced surface wear and electrochemical damage on all Ti6Al4V parts. Such observations imply that care to keep optimum microstructure and corresponding tribological characteristics must be considered under allowable working environments to warrant stable life-time.

Acknowledgments: The authors gratefully acknowledge many valuable discussions with several colleagues at Industrial Engineering and Materials Science and Engineering, and the financial support of University Research Council at Youngstown State University and Precision Printed Parts Network (P3N) grant from Ohio Economic Development Agency.

Author Contributions: Jae Joong Ryu supervised the work and took a major part to the writing process. Sanjay Shrestha performed main mechanical characterizations and data analysis, and took a part to the writing process. Guha Manogharan contributed in AM processing and characterization. Jai K Jung performed image data processing and took a part to the writing process.

Conflicts of Interest: The authors declare no conflict of interest.

\section{References}

1. Emelogu, A.; Marufuzzaman, M.; Thompson, S.M.; Shamsaei, N.; Bian, L. Additive manufacturing of biomedical implants: A feasibility assessment via supply-chain cost analysis. Addit. Manuf. 2016, 11, 97-113. [CrossRef]

2. Mahmoud, D.; Elbestawi, M.A. Lattice Structures and Functionally Graded Materials Applications in Additive Manufacturing of Orthopedic Implants: A Review. J. Manuf. Mater. Process. 2017, 1, 13. [CrossRef]

3. Peron, M.; Torgersen, J.; Berto, F. Mg and Its Alloys for Biomedical Applications: Exploring Corrosion and Its Interplay with Mechanical Failure. Metals 2017, 7, 252. [CrossRef]

4. Harrysson, O.L.A.; Marcellin-Little, D.J.; Horn, T.J. Applications of Metal Additive Manufacturing in Veterinary Orthopedic Surgery. J. Miner. Met. Mater. Soc. 2015, 67, 647-654. [CrossRef]

5. Murr, L.E. Metallurgy of additive manufacturing: Examples from electron beam melting. Addit. Manuf. 2015, 5, 40-53. [CrossRef]

6. Sun, S.-H.; Koizumi, Y.; Kurosu, S.; Li, Y.-P.; Matsumoto, H.; Chiba, A. Build direction dependence of microstructure and high-temperature tensile property of Co-Cr-Mo alloy fabricated by electron beam melting. Acta Mater. 2014, 64, 154-168. [CrossRef]

7. Royhman, D.; Hallab, N.; Jacobs, J.; Mathew, M. Wear mapping-based prediction methods for improved fretting corrosion performance of hip implant modular interfaces. Bone Jt. J. 2017, 99, 128.

8. Molloy, D.O.; Munir, S.; Jack, C.M.; Cross, M.B.; Walter, W.L.; Walter, W.K. Fretting and Corrosion in Modular-Neck Total Hip Arthroplasty Femoral Stems. J. Bone Jt. Surg. 2014, 96, 488-493. [CrossRef] [PubMed]

9. Gepreel, M.A.-H.; Niinomi, M. Biocompatibility of Ti-alloys for long-term implantation. J. Mech. Behav. Biomed. Mater. 2013, 20, 407-415. [CrossRef] [PubMed]

10. Cooper, H.J.; Urban, R.M.; Wixson, R.L.; Meneghini, R.M.; Jacobs, J.J. Adverse Local Tissue Reaction Arising from Corrosion at the Femoral Neck-Body Junction in a Dual-Taper Stem with a Cobalt-Chromium Modular Neck. J. Bone Jt. Surg. 2013, 95, 865-872. [CrossRef] [PubMed]

11. Almanza, E.; Perez, M.J.; Rodriguez, N.A.; Murr, L.E. Corrosion resistance of Ti-6Al-4V and ASTM F75 alloys processed by electron beam melting. J. Mater. Res. Technol. 2017, 6, 251-257. [CrossRef]

12. Ndaliman, M.B.; Bala, K.C.; Khan, A.A.; Ali, M.Y.; Abdullahi, U.; Abdulmumin, A.A. The effects of Sliding Parameters on Dry Wear Characteristics of Ti-6Al-4V Alloy. Adv. Mater. Res. 2015, 1115, 213-216. [CrossRef]

13. Benea, L.; Mardare-Danaila, E.; Mardare, M.; Celis, J.-P. Preparation of titanium oxide and hydroxyapatite on Ti-6Al-4V alloy surface and electrochemical behaviour in bio-simulated fluid solution. Corros. Sci. 2014, 80, 331-338. [CrossRef]

14. Oliver, W.C.; Pharr, G.M. Measurement of hardness and elastic modulus by instrumented indentation: Advances in understanding and refinements to methodology. J. Mater. Res. 2004, 19, 3-20. [CrossRef] 
15. Pharr, G.M.; Strade, J.H.; Oliver, W.C. Critical issues in making small-depth mechanical property measurements by nanoindentation with continuous stiffness measurement. J. Mater. Res. 2009, 24, 653-666. [CrossRef]

16. Hu, Z.; Lynne, K.; Delfanian, F. Characterization of materials' elasticity and yield strength through micro-/nano-indentation testing with a cylindrical flat-tip indenter. J. Mater. Res. 2015, 30, 578-591. [CrossRef]

17. Hu, Z.; Lynne, K.J.; Markondapatnaikuni, S.P.; Delfanian, F. Material elastic-plastic property characterization by nanoindentation testing coupled with computer modeling. Mater. Sci. Eng. A 2013, 587, 268-282. [CrossRef]

18. Gammon, L.M.; Briggs, R.D.; Packard, J.M.; Batson, K.W.; Boyer, R.; Domby, C.W. Metallography and microstructures of titanium and its alloys. In ASM Handbook: Metallography and Microstructures; Voort, G.F.V., Ed.; ASM International: Materials Park, OH, USA, 2004; Volume 9, pp. 899-917.

19. Bortel, E.L.; Charbonnier, B.; Heuberger, R. Development of a Synthetic Synovial Fluid for Tribological Testing. Lubricants 2015, 3, 664-686. [CrossRef]

20. Tan, X.; Kok, Y.; Tan, Y.J.; Descoins, M.; Mangelinck, D.; Tor, S.B.; Leong, K.F.; Chua, C.K. Graded microstructure and mechanical properties of additive manufactured Ti-6Al-4V via electron beam melting. Acta Mater. 2015, 97, 1-16. [CrossRef]

21. Al-Bermani, S.S.; Blackmore, M.L.; Zhang, W.; Todd, I. The Origin of Microstructural Diversity, Texture, and Mechanical Properties in Electron Beam Melted Ti-6Al-4V. Metall. Mater. Trans. A 2010, 41, 3422-3434. [CrossRef]

22. Lu, S.L.; Tang, H.P.; Ning, Y.P.; Liu, N.; Stjohn, D.H.; Qian, M. Microstructure and Mechanical Properties of Long Ti-6Al-4V Rods Additively Manufactured by Selective Electron Beam Melting Out of a Deep Powder Bed and the Effect of Subsequent Hot Isostatic Pressing. Metall. Mater. Trans. A 2015, 46, 3824-3834. [CrossRef]

23. De Formanoir, C.; Michotte, S.; Rigo, O.; Germain, L.; Godet, S. Electron beam melted Ti-6Al-4V: Microstructure, texture, and mechanical behavior of as-built and heat-treated material. Mater. Sci. Eng. A 2016, 652, 105-119. [CrossRef]

24. Kok, Y.; Tan, X.; Tor, S.B.; Chua, C.K. Fabrication and microstructural characterization of additive manufactured Ti-6Al-4V parts by electron beam melting. Virtual Phys. Prototyp. 2015, 10, 13-21. [CrossRef]

25. Doerner, M.F.; Nix, W.D. A method for interpreting the data from depth-sensing indentation instruments. J. Mater. Res. 1986, 1, 601-609. [CrossRef]

26. Lee, Y.-H.; Ji, W.-J.; Kwon, D. Stress measurement of SS400 steel beam using the continuous indentation technique. Exp. Mech. 2004, 44, 55-61. [CrossRef]

27. Giannakopoulos, A.E.; Suresh, S. Determination of elastoplastic properties by instrumented sharp indentation. Scr. Mater. 1999, 40, 1191-1198. [CrossRef]

28. Li, X.X.; Zhou, Y.; Ji, X.L.; Li, Y.X.; Wang, S.Q. Effects of sliding velocity on tribo-oxides and wear behavior of Ti-6Al-4V alloy. Tribol. Int. 2015, 91, 228-234. [CrossRef]

29. Suh, N.P. An overview of the delamination theory of wear. Wear 1977, 44, 1-16. [CrossRef]

30. Yin, H.; Xu, Y.; Li, X.; Chang, W.; Zhou, Y. Design of friction and wear resistant titanium- and cobalt-modified nickel-base repair alloys by spray forming. Mater. Des. 2017, 116, 403-410. [CrossRef]

31. Prabhakar, P.; Sames, W.J.; Smith, R.; Dehoff, R.; Babu, S.S. Computational Modeling of Residual Stress Formation during the Electron Beam Melting Process for Inconel 718. Addit. Manuf. 2015, 7, 83-91. [CrossRef]

32. Kim, K.-S.; Hurtado, J.A.; Tan, H. Evolution of a Surface-Roughness Spectrum Caused by Stress in Nanometer-Scale Chemical Etching. Phys. Rev. Lett. 1999, 83, 3872-3875. [CrossRef]

33. Fang, X.; Li, Y.; Wang, D.; Lu, S.; Feng, X. Surface evolution at nanoscale during oxidation: A competing mechanism between local curvature effect and stress effect. J. Appl. Phys. 2016, 119, 155302. [CrossRef]

34. Long, M.; Rack, H.J. Review: Titanium alloys in total joint replacement-A materials science perspective. Biomaterials 1998, 19, 1621-1639. [CrossRef]

35. Oladokun, A.; Bryant, M.; Hall, R.; Neville, A. The effect of cyclic load on the evolution of fretting current at the interface on metal-on-metal and ceramic-on-metal taper junction of hip prostheses. Bone Jt. J. 2017, $99,68$.

36. Nambu, S.; Obert, R.; Roark, M.; Delvechhio, E.; Linton, D.; Bible, S.; Moseley, J. Accelerated Fretting Corrosion Testing of Modular Necks for Total Hip Arthroplasty. In Modularity and Tapers in Total Joint Replacement Devices; ASTM International: Conshohocken, PA, USA, 2015. [CrossRef] 
37. Kung, M.S.; Markantonis, J.; Nelson, S.D.; Campbell, P. The Synovial Lining and Synovial Fluid Properties after Joint Arthroplasty. Lubricants 2015, 3, 394-412. [CrossRef]

38. De, P.S.; Mishra, R.S.; Smith, C.B. Effect of microstructure on fatigue life and fracture morphology in an aluminum alloy. Scr. Mater. 2009, 60, 500-503. [CrossRef]

39. Balla, V.K.; Soderlind, J.; Bose, S.; Bandyopadhyay, A. Microstructure, mechanical and wear properties of laser surface melted Ti6Al4Valloy. J. Mech. Behav. Biomed. Mater. 2014, 32, 335-344. [CrossRef] [PubMed] 